\title{
DYSTRYBUCJA WYDAWNICTW STOWARZYSZENIA HAŁYCKO-RUSKA MATYCA W POŁOWIE XIX WIEKU: ORGANIZACJA, WYNIKI, OCENY SPOŁECZNE
}

Tematyka publikacji Hałycko-Ruskiej Matycy. Dystrybucja tych publikacji od lat pięćdziesiątych do siedemdziesiątych XIX wieku. Księgarnie i prywatni dystrybutorzy. Statystyka książek towarzystwa wydanych w latach 1864-1873. Rola księgarni Instytutu Stauropigialnego. Reakcja Rusinów galicyjskich na rozpowszechnianie książek Matycy.

SŁOWA KLUCZOWE: historia książki ukraińskiej, historia księgarstwa, księgarnie w Galicji, kształcenie ludu w XIX wieku, duchowieństwo greckokatolickie, towarzystwo Hałycko-Ruska Matyca

W drugiej połowie XIX wieku w Galicji, podobnie jak w innych częściach imperium Habsburgów, można było zaobserwować rosnące zainteresowanie światłych kręgów społeczeństwa podnoszeniem poziomu oświaty wśród ludu. Niezwykle ważne były problemy dostarczenia chłopom na wsi i mieszkańcom miast fachowej wiedzy, istotnej dla rozwoju gospodarczego czy działalności społecznej, zachęcania ich do czytania, samokształcenia oraz rozwoju świadomości obywatelskiej i narodowej. Tematy te były stale obecne na łamach czasopism galicyjskich, zwłaszcza od drugiej połowy lat sześćdziesiątych XIX wieku. Liczne stowarzyszenia zajmowały się kształceniem ludu, w szczególności publikowaniem odpowiedniej literatury; było to zadanie, które wzięła na swoje barki i realizowała ówczesna inteligencja.

Jednym z takich towarzystw oświatowych była Hałycko-Ruska Matyca, powstała w środowisku Rusinów galicyjskich w 1848 roku, podczas Wiosny Ludów. Społeczność ta była szczególnie zainteresowana szerzeniem oświaty wśród ludu, 
gdyż nie tylko nie miała ona własnego państwa, ale także nie mogła odgrywać ważniejszej roli w kraju z powodu braku własnej arystokracji i szlachty oraz niewystarczającej liczby świadomej narodowo inteligencji. $Z$ tego względu za najlepszą podstawę dla swojej działalności uznawali ruskich chłopów, gdyż ci — co prawda w zdecydowanej większości niepiśmienni - kultywowali lokalne język, zwyczaje i tradycje. Jasne było, że to rusińscy mieszkańcy wsi, a w mniejszym stopniu również mieszczanie i nieliczni członkowie rodzącej się dopiero ruskiej inteligencji, powinni w przyszłości stać się wsparciem dla duchowieństwa greckokatolickiego, które w połowie XIX wieku praktycznie w pojedynkę reprezentowało Rusinów przed władzami austriackimi w Galicji.

Trzeba było dużo czasu i wysiłku nie tylko rządowej administracji centralnej i krajowej, ale i ruskiej inteligencji, aby niewykształceni chłopi stali się świadomymi przedstawicielami swojego narodu, zgodnie z wyzwaniami i wymaganiami drugiej połowy XIX wieku. Literatura edukacyjna, wydawana i rozprowadzana przez Hałycko-Ruską Matycę, miała odegrać znaczącą rolę w przyśpieszeniu tego procesu. Stowarzyszenie musiało zmagać się z wieloma problemami, w tym z jednej strony ubóstwem i ignorancją chłopstwa oraz prawie całkowitym brakiem tradycji czytelniczej w życiu codziennym, z drugiej zaś strony z niedostatecznym zrozumieniem jego działalności ze strony ruskiej inteligencji i jej społeczną biernością, pogrążeniem się w swoich prywatnych sprawach. Oczywiście z biegiem czasu sytuacja Rusinów poprawiła się, ale w 1848 roku musieli zaczynać prawie od zera. Przygotowywanie i wydawanie literatury edukacyjnej było dla Matycy tylko częścią działalności oświatowej wśród ludu. Opublikowane książki należało przecież nie tylko dostarczyć potencjalnym czytelnikom, ale — co było nieraz trudniejszym wyzwaniem - przekonać ich o konieczności ich zakupu. $Z$ różnych powodów to nie było łatwe zadanie.

Celem niniejszego artykułu jest zbadanie dystrybucji publikacji towarzystwa Hałycko-Ruska Matyca wśród Rusinów galicyjskich w latach sześćdziesiątych i siedemdziesiątych XIX wieku, jednak z uwzględnieniem także lat wcześniejszych. O przyjęciu takiej cezury czasowej zdecydował fakt, że od połowy lat sześćdziesiątych XIX wieku dystrybucja książek Matycy ożywiła się i stała się bardziej zróżnicowana. Znaczący spadek aktywności stowarzyszenia w drugiej połowie lat siedemdziesiątych XIX wieku negatywnie odbił się również na jego działalności dystrybucyjnej, całkowicie powierzonej Instytutowi Stauropigialnemu we Lwowie.

Obecnie istnieje szereg publikacji naukowych poświęconych działalności Hałycko-Ruskiej Matycy, choć nie doczekała się ona jak dotąd osobnej monografii. Autorzy artykułów lub rozdziałów w opracowaniach zbiorowych z reguły tylko na marginesie podejmowali kwestię dystrybucji wydawnictw towarzystwa - bardziej interesowali ich członkowie i kierownictwo organizacji, a także jej 
działalność wydawnicza i opublikowane przez nią książki. Prowadzonej od lat pięćdziesiątych do siedemdziesiątych XIX wieku dystrybucji tych publikacji poświęcono tylko kilka stron w monografiach ukraińskiego historyka Ołeksija Suchego i niemieckiej badaczki Anny Veroniki Wendland (Sukhyi, 2003, s. 196, 205-208, 245-246; Vendland, 2015, s. 77-79). Najdokładniej temat ten został omówiony ponad dekadę temu przez autora niniejszego artykułu (Sedliar, 2010). Od tego czasu pojawiły się nowe źródła, co skłania do ponownego podjęcia tej kwestii.

Podstawowym materiałem źródłowym dla niniejszego artykułu są przede wszystkim niepublikowane dokumenty Hałycko-Ruskiej Matycy — księga rachunkowa druków przekazanych do sprzedaży oraz korespondencja stowarzyszenia z księgarniami i prywatnymi dystrybutorami jego publikacji. Niestety nie zachowały się wszystkie potrzebne dokumenty, co powoduje, że są okresy, co do których znane są szczegółowe wskaźniki dystrybucji publikacji Matycy, ale są też lata, w przypadku których nie mamy żadnych danych na temat statystyki przekazanych do rozpowszechnienia i sprzedanych książek. Prawie wszystkie te dokumenty są przechowywane w zespole Hałycko-Ruskiej Matycy w Centralnym Państwowym Archiwum Historycznym Ukrainy we Lwowie (zespół 148), ale księga rachunkowa, w której zarejestrowani są sprzedawcy i dane liczbowe dotyczące skierowanych do sprzedaży publikacji stowarzyszenia, znajduje się w zespole Instytutu Stauropigialnego (zespół 129) w tymże archiwum ${ }^{1}$. Autor niniejszego artykułu w czasie pisania swego pierwszego artykułu z 2010 roku nie wiedział o istnieniu tej cennej dokumentacji, dlatego teraz, po wnikliwym przemyśleniu tematu, uważa, że wskazane jest przygotowanie nowego studium na temat dystrybucji wydawnictw Hałycko-Ruskiej Matycy. Innymi ważnymi źródłami są sprawozdania roczne organizacji (ostatnie opublikowane dotyczyło 1871 roku), zawierające ogólne statystyki wpływów finansowych pozyskanych ze sprzedaży książek, a także czasopisma ruskie (zwłaszcza rusofilskie „Słowo”), w których publikowano odpowiedzi Rusinów galicyjskich na temat różnych aspektów działalności Hałycko-Ruskiej Matycy.

Zanim przejdziemy do omówienia dystrybucji publikacji stowarzyszenia w latach sześćdziesiątych i siedemdziesiątych XIX wieku, przedstawmy krótko jej dorobek wydawniczy. W latach $1848-1872^{2}$ organizacja ta opublikowała łącz-

1 Księga rachunkowa kupujących...

2 Statystyka wydawnicza w kontekście dystrybucji książek Hałycko-Ruskiej Matycy jest ograniczona do wzmiankowanego okresu, ponieważ nie zachowały się informacje o książkach wystawianych na sprzedaż po sierpniu 1873 roku. W tymże roku stowarzyszenie nie publikowało książek, więc ostatnie wydawnictwa, które zaoferowano sprzedawcom i których dotyczą istniejące statystyki, pochodzą z 1872 roku. Oczywiście organizacja nadal prowadziła działalność wydawniczą (do 1876 roku, po czym nastąpiła pięcioletnia przerwa) oraz sprzedaż książek, ale nie wiemy, ile pozycji sprzedano pod koniec lat siedemdziesiątych XIX wieku. 
nie 55 książek (patrz tabela 1). W latach 1848-1860 dominowały książki o małej objętości, poniżej 100 stron (16 z 25 tytułów), a w latach 1861-1872 tendencja była odwrotna (spośród 30 pozycji było dziewięć o tak niskiej liczbie stron). Publikacje dla chłopów były niewielkie, większą objętością cechowały się zazwyczaj modlitewniki, podręczniki gimnazjalne do religii i roczniki czasopism naukowych. Pod względem liczby tytułów produkcja wydawnicza Hałycko-Ruskiej Matycy nie wyglądała źle na tle innych tego rodzaju słowiańskich stowarzyszeń. Galicyjscy Rusini wydali mniej publikacji niż Czesi, Słowacy czy Słoweńcy, jednak pod tym względem byli na podobnym poziomie co Serbowie i Chorwaci, zostawiając w tyle Matice moravską (Kimball, 1973, s. 71).

Tab. 1. Statystyka publikacji Hałycko-Ruskiej Matycy (1848-1872)

\begin{tabular}{|l|c|c|c|}
\hline \multicolumn{1}{|c|}{ Lata } & $1848-1860$ & $1861-1872$ & Razem \\
\hline Literatura edukacyjna & 7 & 10 & 17 \\
\hline Modlitewniki, lektura religijna i pouczająca & 8 & 5 & 13 \\
\hline Literatura naukowa i popularnonaukowa & 3 & 5 & 8 \\
\hline Literatura rolnicza & 1 & 1 & 2 \\
\hline Periodyki (naukowe), roczniki & 3 & 7 & 10 \\
\hline Inne publikacje & 3 & 2 & 5 \\
\hline Razem & 25 & 30 & 55 \\
\hline
\end{tabular}

Źródło: opracowanie własne.

W pierwszych latach istnienia organizacji książki, które mogły być używane w szkole podstawowej, były przez nią traktowane priorytetowo, ponieważ wtedy (zwłaszcza w latach 1849-1850) szybko rosła liczba placówek z ukraińskim (ruskim) językiem nauczania. W związku z tym konieczne było wypracowanie najskuteczniejszego sposobu dostarczania i sprzedaży tego rodzaju literatury edukacyjnej. Najlepszą opcją byłaby sprzedaż książek bezpośrednio na wsi, ponieważ zdecydowana większość chłopów galicyjskich, a być może także wiejskich księży czy nauczycieli, nie miała ani ochoty, ani możliwości, by zakupić potrzebne tytuły we Lwowie. Biorąc pod uwagę również fakt, że organizacja ukraińskiego życia publicznego w Galicji w tym czasie była ściśle powiązana z Kościołem greckokatolickim, nie dziwi fakt, że przywódcy Matycy zdecydowali się oprzeć dystrybucję na dekanatach kościelnych.

Proces tworzenia sieci prywatnych dystrybutorów na prowincji trwał od około 1850 do 1852 roku. Wcześniej wydawnictwa Matycy można było nabyć we Lwowie tylko u kilku związanych ze stowarzyszeniem osób. 1 marca 1850 roku 
drugie walne zgromadzenie stowarzyszenia postanowiło zwrócić się do wszystkich dziekanów o podanie nazwisk księży (po dwóch na dekanat), którzy bez pobierania pieniędzy za swoją działalność sprzedawaliby publikacje towarzystwa ([Ukhvaly Soboru rus'kykh vchenykh...], 1850, s. 169). Później prośba Matycy została poparta stosownymi apelami do konsystorzy greckokatolickich we Lwowie ( 28 czerwca 1850 roku) i Przemyślu (22 lipca tego samego roku) ${ }^{3}$. W rezultacie w wielu (ale nie wszystkich) dekanatach pod koniec 1850 roku i na początku kolejnego zaczęły pojawiać się komisje (złożone z trzech księży), które sprzedawały książki Matycy. Ponadto udało się uzgodnić dystrybucję publikacji z dyrekcją Instytutu Stauropigialnego i w marcu 1850 roku stowarzyszenie przekazało po 100 egzemplarzy każdego tytułu do ksęgarni Instytutu . Wydawnictwa Matycy w latach pięćdziesiątych XIX wieku sprzedawano także w księgarniach Andrzeja Gergowicza we Lwowie, Johanna Rosenheima w Tarnopolu i Samborze oraz B.D. Neranziego w Brzeżanach; niewykluczone, że książki były rozprowadzane również w Haliczu przez Romualda Lewicha.

W ten sposób już na początku lat pięćdziesiątych XIX wieku zorganizowano sieć dystrybucji publikacji Hałycko-Ruskiej Matycy, która funkcjonowała również w późniejszym okresie. Tworzyły ją: księgarnia Instytutu Stauropigialnego, gdzie sprzedawano najwięcej książek, inne księgarnie oraz prywatni dystrybutorzy we Lwowie (jak ksiądz kanonik Josyf Kulczycki) i na prowincji. Sprzedawcy lwowscy otrzymywali książki bezpośrednio z magazynu Matycy, który pierwotnie mieścił się w Greckokatolickim Seminarium Duchownym, a później w Domu Ludowym (Narodnyj Dim). Trudniejsze było przekazywanie publikacji dystrybutorom spoza Lwowa. Aby uniknąć kosztów związanych z wysyłką pocztą, zarząd towarzystwa, który odpowiadał również za dystrybucję wydawnictw, zachęcał sprzedawców do szukania innych sposobów dostawy. $Z$ reguły książki odbierali księża z poszczególnych dekanatów przy okazji załatwiania prywatnych spraw we Lwowie. Czasami publikacje wysyłano na prowincję także pocztą.

Generalnie kierownictwo Hałycko-Ruskiej Matycy nie uważało, zwłaszcza w pierwszej połowie lat pięćdziesiątych XIX wieku, przyjętej przez siebie organizacji dystrybucji własnych publikacji za złą lub nieskuteczną, choć oczywiście były pewne problemy. Przede wszystkim nie udało się zaangażować w tę działalność wszystkich dziekanów, więc były rejony, gdzie książki Matycy nie były nawet znane (Dopytailo, 1851). Stało się tak z kilku powodów, spośród których wyróżnić możemy: 1. bierność księży (zwłaszcza dziekanów) z niektórych dekanatów; 2. oddalenie danego dekanatu od Lwowa - duża odległość często uniemożliwiała doręczenie przesyłek przez okazjonalnych kurierów; 3. zbyt skromna liczba

3 List zarządu Hałycko-Ruskiej Matycy..., 15 (27) maja 1852; list księdza Stefana Krynickiego..., 4 października 1850.

4 Protokoł posiedzenia zarządu..., 27 marca 1850. 
istniejących szkół podstawowych w dekanacie, gdyż księża zainteresowani byli rozpowszechnianiem przede wszystkim elementarzy, czytanek i modlitewników dla uczniów szkół parafialnych i trywialnych. Tytuły wydawane przez Matycę statystycznie sprzedawało więcej dekanatów w archidiecezji lwowskiej niż w diecezji przemyskiej, głównie ze względu na lepsze kontakty miejscowych księży ze Lwowem. Z reguły najmniej aktywni byli dziekani z terenów górskich i okolic ukraińsko-polskiej granicy etnicznej.

Dystrybutorzy prywatni (w dokumentach Matycy za lata 1849-1861 odnotowano ich $119^{5}$ ) — stu z nich było księżmi, było też wśród nich po trzechczterech nauczycieli i uczniów szkół podstawowych, a resztę stanowili świeccy inteligenci lub osoby, których status nie może być ustalony — pracowali za darmo. Otrzymywali książki na pewną kwotę, musieli je sprzedać, a następnie wszystkie uzyskane w ten sposób pieniądze wysłać do Lwowa. Ich postępowaniem kierowało przekonanie, że realizują misję patriotyczną, która nie wymaga zapłaty. Księgarnie natomiast sprzedawały książki Matycy za opłatą. Na przykład księgarnia Instytutu Stauropigialnego otrzymywała początkowo $10 \%$, a od 7 czerwca 1852 roku $12 \%$ wartości każdej sprzedanej książki ${ }^{6}$. J. Rosenheim otrzymywał $15 \%$ nagrody ([Sprawozdanie J. Rosenheima, 16 stycznia 1854], 1854, 1. 38), a B.D. Neranzi $10 \%$ ([List do B.D. Neranziego], 1855, 1. 24).

Łącznie w latach 1849-1860 Hałycko-Ruska Matyca uzyskała ze sprzedaży własnych wydawnictw 9030 złotych reńskich i 21 krajcarów (waluty Cesarstwa Austriackiego). Kwota ta prawie całkowicie zrekompensowała wydatki stowarzyszenia poniesione na działalność wydawniczą we wspomnianym okresie (10 002 złotych reńskich i 39 krajcarów). Ponadto w magazynie Matycy pozostały książki o wartości 4978 złotych reńskich i 72 krajcarów, zaś u sprzedawców znajdowały się publikacje o wartości 4159 złotych reńskich i 16 krajcarów. Kwoty pochodzące $\mathrm{z}$ dystrybucji książek w tym czasie przeważały, ale nie dominowały, w strukturze zysków towarzystwa, stanowiąc 53,08\% ich całości (Sedliar, 2010, s. 43).

Przyjrzyjmy się dokładniej dynamice przekazywania publikacji Hałycko-Ruskiej Matycy do dystrybucji i odbierania pieniędzy od sprzedawców. W ciągu pierwszych pięciu lat (do 1854 roku) poziom przepływu publikacji i zysków finansowych był dość wysoki — do sprzedaży przekazywano książki o średniej wartości ponad 2000 złotych reńskich rocznie, a od sprzedawców otrzymywano przeciętnie 1200 złotych reńskich rocznie. W drugiej połowie lat pięćdziesiątych XIX wieku liczby te znacznie spadły: do rozpowszechnienia przekazano książki o wartości około 480 złotych reńskich, a za ich sprzedaż otrzymywano od sprzedawców około 430 złotych reńskich (Sedliar, 2010, s. 44). Tę istotną różnicę można

\footnotetext{
${ }^{5}$ Księga rachunkowa kupujących..., 1. 8-50.

${ }^{6}$ List Instytutu Stauropigialnego..., 14 lipca 1853.
} 
wytłumaczyć, po pierwsze, gwałtownym spadkiem aktywności wydawniczej Matycy po 1852 roku (w sprzedaży pojawiało się niewiele nowych publikacji), a po drugie, znacznym osłabieniem aktywności nabywczej potencjalnych czytelników. Stało się tak zarówno ze względów ekonomicznych (połowa lat pięćdziesiątych to czas nieurodzaju i trudności gospodarczych), jak i za sprawą wspomnianego już braku nowych ciekawych wydawnictw Matycy. Według stanu na 1 stycznia 1861 roku sprzedano połowę $(49,7 \%)$ wszystkich książek wydanych przez stowarzyszenie, nieco ponad jedna czwarta $\mathrm{z}$ nich $(27,4 \%)$ pozostała w magazynie, a 22,9\% znajdowało się u sprzedawców. Do końca dekady sprzedano dwie trzecie publikacji $(68,46 \%)$ (Sedliar, 2010, s. 44).

Jak wspomniano powyżej, dystrybutorów wydawnictw Matycy można podzielić na trzy grupy: 1. księgarnia Instytutu Stauropigialnego (sprzedała książki o wartości 3418 złotych reńskich i 32 krajcarów - co stanowiło 43,26\% całości sprzedaży); 2. inne księgarnie (1008 złotych reńskich i 37 krajcarów — 12,76\%); 3. dystrybutorzy prywatni (3475 złotych reńskich i 51 krajcarów - 43,98\%). Tak więc księgarnia Instytutu Stauropigialnego i prywatni dystrybutorzy rozprowadzili książki za mniej więcej taką samą kwotę. Jeśli jednak w latach 18501854 Instytut sprzedawał wiele wydawnictw (uzyskując dochód w wysokości około 550 złotych reńskich rocznie), to później jego aktywność w tym zakresie gwałtownie spadła (roczny przychód z tego tytułu zmalał do 100 złotych reńskich). Prywatni dystrybutorzy byli bardziej stabilni pod tym względem i sprzedawali książki o wartości 350 złotych reńskich rocznie (ich spadek aktywności nastąpił dopiero w latach 1856-1857) (Sedliar, 2010, s. 45).

Teraz bardziej szczegółowo omówimy pracę prywatnych dystrybutorów. $Z$ reguły we Lwowie starano się przygotować pierwszą partię złożoną z egzemplarzy każdej ze wszystkich wydanych wówczas przez Matycę publikacji; następna składała się już z literatury zamówionej przez sprzedawcę (książki te przeznaczano przeważnie dla uczniów szkół podstawowych) i nowych wydań; czasem dodawano też trochę starszych publikacji, ale sprzedawały się one bardzo słabo. Cena partii książek przekazywanych do niektórych dekanatów mogła wahać się od kilku do kilkuset złotych reńskich. Po otrzymaniu publikacji osoba odpowiadająca z ramienia dekanatu za ich dystrybucję (często był to sam dziekan) sprzedawała je samodzielnie lub powierzała część z nich innym księżom. Chłopi kupowali podręczniki do szkół i modlitewniki, najczęściej czyniąc to podczas wizytacji miejscowej szkoły przez dziekana (który był jednocześnie wizytatorem szkół nadzorowanych przez konsystorz greckokatolicki), księża kupowali literaturę popularnonaukową przy okazji soborczyku dekanalnego lub osobistych wizyt swoich kolegów-sprzedawców. Jak już wspomniano, najlepiej sprzedawały się elementarze, czytanki i małe modlitewniki. 
Nieco inaczej przedstawiała się struktura asortymentu sprzedawanego w księgarniach. Przede wszystkim wśród rozprowadzanych tam publikacji znacznie wyższy był udział literatury naukowej i popularnonaukowej. Na przykład w księgarni Instytutu Stauropigialnego w latach 1852-1853 sprzedano 71,8\% książek według ustalonej ceny (a odliczając elementarze, czytanki i modlitewniki - 37,2\% ${ }^{7}$, w latach $1853-1854$ wskaźniki te znajdowały się na poziomie $47,6 \%$ i $42 \%{ }^{8}$, zaś w latach $1854-1855$ drugi z nich wynosił $47,7 \%{ }^{9}$. Tak więc książki kupowane głównie przez wykształconych czytelników stanowiły około $40 \%$ sprzedanych we Lwowie w pierwszej połowie lat pięćdziesiątych XIX wieku wydawnictw Hałycko-Ruskiej Matycy, podczas gdy w dekanatach na prowincji wskaźnik ten był dwukrotnie niższy. Należy również zauważyć, że wielu aktywnych, inteligentnych czytelników ze wsi i miasteczek często nabywało interesujące ich książki we Lwowie, ponieważ tam ich asortyment był większy; nie bez znaczenia było też to, że w mieście szybciej można było dostać nowości.

Tak więc rozwój dystrybucji publikacji Hałycko-Ruskiej Matycy w latach pięćdziesiątych XIX wieku można podzielić na dwa okresy: w pierwszej połowie dekady w związku z aktywną działalnością wydawniczą stowarzyszenia rozprowadzano dużo książek, zwłaszcza w księgarniach. Mniej więcej w latach 1855-1856 sprzedaż publikacji Matycy znacznie spadła; zamarła w księgarniach, spadła u prywatnych dystrybutorów; było wielu sprzedawców, którzy przez lata nic nie sprzedali.

W latach 1860-1861 w Cesarstwie Austriackim zakończył się okres neoabsolutyzmu; zmiany polityczne w państwie spowodowały ożywienie życia publicznego i zachęciły istniejące już organizacje publiczne do większej aktywności. W tym czasie galicyjscy Ukraińcy pokładali w Matycy duże nadzieje i liczyli, że towarzystwo to stanie się siłą napędową pracy kulturalnej, narodowej i oświatowej w kraju.

Jednym z pilnych problemów, jakie musiało rozwiązać kierownictwo Hałycko-Ruskiej Matycy w nowej sytuacji, była dystrybucja własnych wydawnictw. $\mathrm{Na}$ początku 1862 roku księgarnia Instytutu Stauropigialnego była zamknięta, sprzedawcy na prowincji nie odsyłali do Lwowa pieniędzy za sprzedane książki, a o tych niesprzedanych nic nie było wiadomo. Sytuacja ta poprawiła się 1 lipca 1862 roku, kiedy ponownie otwarto księgarnię Instytutu Stauropigialnego, a zarząd stowarzyszenia postanowił przekazać jej swoje publikacje w celu ich dystrybucji. Rabat (prowizja) dla księgarni wynosił $20 \%$ ustalonej ceny sprzedanych książek ${ }^{10}$.

Nadal niepewna pozostawała sytuacja z prywatnymi dystrybutorami. Większość osób wymienionych w dokumentach Matycy jako sprzedawcy jej wydawnictw nie dawała znaku życia. Kierownictwo towarzystwa nawet nie

7 Sprawozdanie Instytutu Stauropigialnego..., 1853, 1. 3v-4.

8 Sprawozdanie Instytutu Stauropigialnego..., 1854, 1. 44.

9 Sprawozdanie Instytutu Stauropigialnego..., 1855, 1. 52.

10 Protokół posiedzenia zarządu..., 1856. 
wiedziało dokładnie, komu i w jakiej liczbie przekazano w minionej dekadzie książki. Z jednej strony pojawiły się nieścisłości w dokumentacji biurowej samej organizacji, z drugiej strony w ciągu 10-12 lat zmieniły się osoby odpowiedzialne z ramienia dekanatów za nadesłane do sprzedaży publikacje Matycy. Niektóre z nich zmarły, część przeniosła się do nowych parafii, zmienili się dziekani itp., a tomy, które przekazywano sobie z rąk do rąk, niszczały w miarę upływu czasu. W większości przypadków chodziło o mało popularne publikacje, w przypadku których dystrybutorzy nie mieli już nadziei na ich sprzedaż. Niektóre odesłali do Lwowa, a o części z nich po prostu zapomnieli. Brak źródeł nie pozwala ustalić nawet w przybliżeniu tego rodzaju strat, ale oczywiste jest, że Matyca musiała wykreślić z ksiąg rachunkowych pewną część wysyłanych na sprzedaż publikacji.

Władze towarzystwa wielokrotnie próbowały ustalić rzeczywisty stan jego wydawnictw w dekanatach, nakłaniając dziekanów i inne osoby, które posiadały książki, do zgłaszania, ile i jakich publikacji mają na stanie. Zgodnie z podjętą na posiedzeniu z 26 lutego 1864 roku decyzją rozesłano do nich odpowiednie apele ${ }^{11}$, później o sprawie rozstrzygnąć miało walne zgromadzenie Matycy w tym samym roku $^{12}$. Oczywiście nie udało się zebrać wszystkich informacji, więc w 1868 roku zarząd towarzystwa musiał ponownie zaapelować do dekanatów, aby dziekani przesłali dokładne dane o znajdujących się u nich publikacjach ${ }^{13}$.

Mimo tych problemów Matyca kontynuowała współpracę z prywatnymi dystrybutorami w latach sześćdziesiątych XIX wieku i później, gdyż księgarnie w miastach nie mogły ich w tej działalności zastąpić. Po walnym zgromadzeniu organizacji w 1864 roku zaczęto ponownie rejestrować w jej księdze rachunkowej książki przekazywane do sprzedaży. Część egzemplarzy trafiła do prywatnych sprzedawców, których liczba była jednak znacznie mniejsza niż w poprzedniej dekadzie - przed 1870 rokiem zarejestrowano tylko 18 dystrybutorów ${ }^{14}$.

Pod koniec lat sześćdziesiątych XIX wieku kierownictwo Hałycko-Ruskiej Matycy ostatecznie zdało sobie sprawę z potrzeby zmian w organizacji dystrybucji jej wydawnictw na prowincji. Oparcie sprzedaży wyłącznie na bezinteresowności prywatnych sprzedawców nie mogło być odpowiednio efektywne, choćby ze względu na niewystarczającą ich liczbę. W efekcie Ukraińcy galicyjscy na ogół niewiele wiedzieli o publikacjach Matycy, chociaż władze towarzystwa regularnie przesyłały do gazet informacje o nowych książkach. W rezultacie zarząd Matycy na posiedzeniu w dniu 21 czerwca (3 lipca nowego stylu) 1869 roku omawiał możliwe zmiany w schemacie rozpowszechniania wydawnictw organizacji na prowincji. Postanowiono „skierować sprawę do wielebnych duszpasterzy miejsc,

11 Zob. „L'viv, dnia 26. Liutoho 1864”..., s. 55-56.

12 „Spravosdan'ie s zasidanii »Halitsko-Russkoi Matitsy« v dniakh...”, 1865, 1. XL.

13 Adres zarządu Hałycko-Ruskiej Matycy..., 18 (30) III 1868, 1. 35v-36v.

14 Księga rachunkowa kupujących..., 1. 105-115. 
w których ludzie gromadzą się licznie na odpustach parafialnych, tak aby wskazali jednego ze swoich znajomych, który podejmie się sprzedaży tych książek za uzgodnioną opłatą" („Novynky”, 1869).

Na prośbę władz Matycy kwestia sprzedaży jej książek została szczegółowo omówiona 27 sierpnia (8 września) 1870 roku na walnym zgromadzeniu towarzystwa. W dyskusji przewijały się głównie trzy wątki: 1. powolne rozprowadzanie publikacji (ksiądz Teofil Pawłykiw tłumaczył to następująco: „Do tej pory sprzedaż książek ograniczała się, z niewielkim wyjątkiem, do samego Lwowa"); 2. konieczność ustalenia wynagrodzenia dla sprzedawców (ksiądz Iwan Huszalewicz proponował nawet jego wysokość dla osób, które zapłacą od razu całość należności za książki — $25 \%$ ich ceny); 3 . potrzeba uzyskania gwarancji pieniężnej od osób, które przyjmują wydawnictwa do sprzedaży. Pojawiły się również propozycje dalszego nieprzekazywania wynagrodzenia dystrybutorom i rekrutowania ich spośród „dobrych ruskich patriotów”, jednak po debacie podjęto jednogłośną decyzję o wynagradzaniu sprzedających, a konkretne szczegóły (w tym wysokość zapłaty) miały ustalić władze organizacji („Otchet zasidaniia obshchogo sobraniia chlenov...", [1871], s. 131-132). W protokołach z posiedzeń zarządu Matycy z okresu po 1870 roku nie ma jednak informacji o wyznaczeniu wynagrodzenia dla prywatnych dystrybutorów.

Ich liczba znacznie wzrosła po wspomnianym walnym zgromadzeniu, a zwłaszcza od 1871 roku. Przestano więc kierować apele do konsystorzy i dziekanów, a kierownictwo Matycy zwracało się bezpośrednio do potencjalnych sprzedawców. W latach 1864-1873 zarejestrowano 68 dystrybutorów, w tym 50 księży greckokatolickich ${ }^{15}$. Jak zatem widać, w porównaniu z latami pięćdziesiątymi XIX wieku wyraźnie zmniejszyła się liczba prywatnych sprzedawców, spadł także odsetek księży wśród nich (73,5\% w stosunku do 84\% dwadzieścia lat wcześniej), choć nadal był on bardzo znaczący. Przesyłki dla nich były bardzo zróżnicowane pod względem liczby książek i ich ceny, które wynosiły od kilku do 100-150 złotych reńskich. Największe partie wydawnictw przekazywano duchownym ze Lwowa i Przemyśla; jedną z nich w kwocie ponad 100 złotych reńskich (141 zł reńskich i 57 krajcarów) na początku 1872 roku otrzymał dla dekanatu prowincjalnego dziekan dukielski z Łemkowszczyzny, ksiądz Antoni Głuszkiewicz ${ }^{16}$.

15 Ta liczba jest mniejsza niż rzeczywista liczba osób, które otrzymały książki Hałycko-Ruskiej Matycy. Nazwiska niektórych dystrybutorów nie są wymieniane w księdze rachunkowej, być może dlatego, że zapłacili oni za otrzymane książki z góry, a towarzystwo nie musiało dalej kontaktować się z nimi w związku ze sprzedażą swoich publikacji. Ponadto nie uwzględnia się osób, które otrzymały jedną lub więcej książek za bardzo niewielką kwotę. Nie można ich uznać za dystrybutorów wydawnictw Matycy, ponieważ prawdopodobnie brali oni książki dla siebie albo dla swoich bliskich lub znajomych.

16 Księga rachunkowa kpujących..., 1. 118-119. 
Innym źródłem dochodu ze sprzedaży książek towarzystwa były księgarnie. Wśród nich szczególne miejsce, podobnie jak w poprzedniej dekadzie, zajmowała placówka należąca do Instytutu Stauropigialnego, która była największym sprzedawcą publikacji Matycy. Korzystano też z usług innych księgarni, chociaż stowarzyszenie nie miało określonej polityki współpracy z nimi. Ich lista została ustalona po prostu na podstawie zgłoszeń ich właścicieli do zarządu Matycy z prośbą o przekazanie im niektórych książek do sprzedaży. W latach 1864-1873 wydawnictwa te sprzedawano w piętnastu księgarniach zlokalizowanych w jedenastu miastach (księgarnie Milikowskiego we Lwowie i Stanisławowie; Gergowicza we Lwowie; Wilda we Lwowie; braci Jeleniów w Przemyślu; Malewskiego w Brzeżanach; Erdsteina w Stanisławowie; Csillika w Tarnopolu; Rosenheima w Brodach; Pardiniego w Czerniowcach; Bogussa w Jarosławiu; Zadembskiego w Kołomyi; Millera w Stryju i Buczaczu; Orensteina w Kołomyi). Ponadto część książek była rozprowadzana bezpośrednio w lwowskim magazynie Matycy.

Jak wyglądał proces przekazywania wydawnictw stowarzyszenia $\mathrm{z}$ jego magazynu na sprzedaż? Według stanu na dzień 21 lipca 1864 roku (początek walnego zgromadzenia) Matyca dysponowała publikacjami o wartości 8042 złotych reńskich i 91 krajcarów $^{17}$. Po walnym zgromadzeniu w 1865 roku jej zarząd przekazał wiele książek z magazynu, tak że rok później wartość pozostałych tam książek wynosiła szacunkowo około 6100-6300 złotych reńskich. W tym czasie organizacja nie publikowała prawie żadnych nowych tytułów. Taki stan rzeczy utrzymywał się do 1869 roku, kiedy to ze względu na obniżkę cen wydanych w pierwszej połowie dekady podręczników gimnazjalnych do religii wartość książek znajdujących się w magazynie spadła do 5000-5250 złotych reńskich. Później, na początku lat siedemdziesiątych XIX wieku, wskutek intensyfikacji działalności wydawniczej Matycy jednoczesnie wzrosły liczby zarówno egzemplarzy nowych publikacji znajdujących się w magazynie, jak i przekazanych na sprzedaż egzemplarzy. Wartość książek w magazynie Matycy wahała się wówczas między 4900 a 5150 złotych reńskich ${ }^{18}$.

Były one przekazywane także członkom założycielom towarzystwa, którzy mieli prawo do bezpłatnych egzemplarzy. Należy zauważyć, że większość z nich nie korzystała ze swoich praw i nie zabierała dla siebie tych tytułów. W latach 1865-1867 wartość książek przekazywanych bezpłatnie wynosiła od 35 do 70 złotych reńskich, a w latach 1868-1872 od 100 do 280 złotych reńskich. Reszta książek trafiła do księgarń i prywatnych dystrybutorów. Dynamikę tego procesu można zobaczyć w tabeli 2.

17 Księga rachunkowa kupujących..., 1. 98.

18 Księga rachunkowa kupujących..., 1. 96-104. 
Tab. 2. Wartość książek Hałycko-Ruskiej Matycy przekazanych sprzedawcom w latach 1864-1873

\begin{tabular}{|c|c|c|c|c|c|c|c|c|}
\hline \multirow[t]{2}{*}{ Rok } & \multicolumn{2}{|c|}{$\begin{array}{c}\text { Księgarnia } \\
\text { Instytutu } \\
\text { Stauropigialnego }\end{array}$} & \multicolumn{2}{|c|}{ Inne księgarnie } & \multicolumn{2}{|c|}{$\begin{array}{c}\text { Prywatni } \\
\text { dystrybutorzy }\end{array}$} & \multicolumn{2}{|c|}{ Razem } \\
\hline & $\begin{array}{l}\text { złote } \\
\text { reńskie }\end{array}$ & $\begin{array}{l}\text { kraj- } \\
\text { cary }\end{array}$ & $\begin{array}{l}\text { złote } \\
\text { reńskie }\end{array}$ & $\begin{array}{l}\text { kraj- } \\
\text { cary }\end{array}$ & $\begin{array}{l}\text { złote } \\
\text { reńskie }\end{array}$ & $\begin{array}{l}\text { kraj- } \\
\text { cary }\end{array}$ & $\begin{array}{l}\text { złote } \\
\text { reńskie }\end{array}$ & $\begin{array}{l}\text { kraj- } \\
\text { cary }\end{array}$ \\
\hline $\begin{array}{l}1864 \\
(21 \text { lipca - } \\
31 \text { grudnia) }\end{array}$ & 269 & 66 & 31 & 50 & 111 & 70 & 412 & 86 \\
\hline 1865 & 754 & 10 & 57 & 40 & 213 & 13 & 1024 & 63 \\
\hline 1866 & 175 & - & 9 & - & 18 & 85 & 202 & 85 \\
\hline 1867 & 110 & - & 45 & 75 & 11 & 5 & 166 & 80 \\
\hline 1868 & \multicolumn{6}{|c|}{ brak danych } & 325 & 32 \\
\hline 1869 & 129 & 50 & 64 & 67 & 58 & 2 & 252 & 19 \\
\hline 1870 & 201 & 40 & 13 & 80 & 459 & 66 & 674 & 86 \\
\hline 1871 & 189 & 86 & 185 & 78 & 829 & 41 & 1205 & 5 \\
\hline 1872 & 504 & 40 & 464 & 92 & 777 & 76 & 1747 & 8 \\
\hline $\begin{array}{l}1873 \text { (do } \\
2 \text { sierpnia) }\end{array}$ & 203 & 15 & 81 & 40 & 187 & 25 & 471 & 80 \\
\hline $\begin{array}{l}\text { Razem (bez } \\
1868 \text { roku) }\end{array}$ & \multicolumn{2}{|c|}{2537,07} & \multicolumn{2}{|c|}{954,22} & \multicolumn{2}{|c|}{2666,83} & \multicolumn{2}{|c|}{6158,12} \\
\hline
\end{tabular}

Źródło: opracowanie własne na podstawie: Księga rachunkowa kupujących..., 1. 105-125.

Jak widać, można wyróżnić trzy okresy aktywności Hałycko-Ruskiej Matycy w zakresie sprzedaży książek. W drugiej połowie 1864 roku i w 1865 roku przekazano do sprzedaży publikacje o wartości 990 złotych reńskich rocznie, w latach 1866-1869 kwota ta wyniosła 235 złotych reńskich rocznie, a w latach 1870-1873 - 1140 złotych reńskich (w latach 1871-1872 nawet 1475 złotych reńskich) rocznie. Wynikało to przede wszystkim ze skali działalności wydawniczej stowarzyszenia. W połowie lat sześćdziesiątych XIX wieku, kiedy prawie nie publikowano nowych tytułów, sprzedawcom dostarczono publikacje z lat poprzednich. W drugiej połowie dekady Matyca skoncentrowała się na wydawaniu „Sbornika Naukowego", który był sprzedawany tylko w księgarni Instytutu Stauropigialnego. Wreszcie po 1869 roku, wobec publicznej krytyki tego stanu rzeczy, towarzystwo postanowiło ożywić zarówno działalność wydawniczą, jak i kolportaż swoich książek, zwłaszcza tych nowych. Szczyt jego aktywności przypadł na lata 1871-1872, zaś 
od 1873 roku można zaobserwować początki jej osłabienia, ale brak dokumentacji finansowej nie pozwala oszacować liczby przekazanych do sprzedaży książek.

Jeśli chodzi o sprzedawców wydawnictw Hałycko-Ruskiej Matycy, to widać wyraźnie, że w latach 1864-1869 dominowała wśród nich księgarnia Instytutu Stauropigialnego, podczas gdy na początku lat siedemdziesiątych XIX wieku ponad połowa (według ustalonej ceny) przekazanych książek trafiła do prywatnych dystrybutorów. Było to wynikiem podejmowanych przez kierownictwo organizacji prób zwiększenia obecności jej wydawnictw na prowincji. Łącznie w latach 1864-1873 przesłano Instytutowi 41,2\% książek, innym księgarniom 15,5\%, a prywatnym dystrybutorom 43,3\%. Jak widać, podział publikacji Hałycko-Ruskiej Matycy między różne kategorie sprzedawców w tym czasie był z grubsza podobny do tego z poprzedniej dekady. Jedyna różnica polegała na wzroście liczby księgarń. Nawiasem mówiąc, najwięcej publikacji Matycy otrzymały placówki braci Jeleniów w Przemyślu (1865-1872, o wartości 188 złotych reńskich i krajcarów); Milikowskiego w Stanisławowie (1868-1873, o wartości 170 złotych reńskich i 34 krajcarów); Zadembskiego w Kołomyi (1872, o wartości 161 złotych reńskich); Milikowskiego we Lwowie (1872, o wartości 89 złotych reńskich i 25 krajcarów); Erdsteina w Stanisławowie (1864-1865, o wartości 78 złotych reńskich); Gergowicza we Lwowie (1865-1872, o wartości 69 złotych reńskich i 40 krajcarów; Csillika w Tarnopolu (1871-1872, o wartości 69 złotych reńskich i 15 krajcarów) ${ }^{19}$. Jest oczywiste, że liczby te są bardzo skromne w porównaniu z wartością książek przekazanych do księgarnii Instytutu Stauropigialnego. Dlatego w miastach, w których działały wspomniane księgarnie prywatne (na przykład w Przemyślu), książki Matycy były w tym samym czasie sprzedawane także przez osoby prywatne.

Asortyment tytułów rozprowadzanych przez stowarzyszenie był różny. Nie istniały tutaj żadne określone prawidłowości. Wyraźnie widać, że publikacje będące częścią większych partii były bardziej zróżnicowane tematycznie. Do księgarni Instytutu Stauropigialnego trafiały wszystkie wydawnictwa Hałycko-Ruskiej Matycy; po sprzedaży wszystkich będących na stanie egzemplarzy danego tytułu księgarnia zamawiała następną dostawę, którą otrzymywała bardzo szybko, bowiem jej współpraca z organizacją na tym polu układała się bardzo harmonijnie. Kontakty innych księgarzy z ruskim towarzystwem oświatowym były raczej sporadyczne; wśród książek otrzymanych przez nich na sprzedaż od Matycy dominowały podręczniki gimnazjalne do religii dla grekokatolików oraz modlitewniki wydane w pierwszej połowie lat sześćdziesiątych XIX wieku. Na przykład księgarnia Csillika w Tarnopolu w okresie od 19 września 1871 roku do 30 grudnia następnego roku otrzymała trzynaście publikacji w 96 egzemplarzach o wartości 69 złotych reńskich i 15 krajcarów. Prawie wszystkie z nich były podręcznikami

19 Księga rachunkowa kupujących..., 1. 105-125; List braci Jeleniów, 1866. 
gimnazjalnymi do nauki religii i modlitewnikami. 1 czerwca 1873 roku tarnopolski księgarz zwrócił dziesięć egzemplarzy trzech publikacji. Księgarnia Milikowskiego we Lwowie w okesie od 15 czerwca do 12 października 1872 roku dostała książki Matycy o wartości 89 złotych reńskich i 25 krajcarów (w sumie 187 egzemplarzy 17 różnych publikacji). 3 lutego kolejnego roku zwróciła 92 egzemplarzy jedenastu publikacji o wartości 55 złotych reńskich i 58 krajcarów. Wśród niesprzedanych książek znalazły się 84 egzemplarze starych podręczników do religii dla grekokatolików, na które zapotrzebowanie we Lwowie było już niewielkie ${ }^{20}$.

Oczywiście księgarze polegali przede wszystkim na Rusinach z kręgów inteligencji. W latach 1871-1873 w składanych przez nich w zarządzie Matycy zamówieniach na jej publikacje znajdowały się także tanie książki dla „zwykłych” ludzi, ale ich łączna cena zawsze była mniejsza niż w przypadku modlitewników i literatury dla inteligencji. Z tego można wywnioskować, że ruska książka jako towar dla księgarzy innej narodowości kojarzyła się przede wszystkim z Kościołem greckokatolickim. Prowincjonalni księża tej konfesji, którzy kolportowali publikacje Hałycko-Ruskiej Matycy, bardziej koncentrowali się na potrzebach chłopów, choć rozpowszechniali także książki wśród inteligencji. Między innymi dziekan skalatski, ksiądz Ihnatij Halka, w okresie od 12 listopada 1871 roku do 30 grudnia 1872 roku czterokrotnie otrzymywał książki od Matycy. W sumie pozyskał 220 egzemplarzy piętnastu różnych publikacji o wartości 89 złotych reńskich i 90 krajcarów. Wśród nich było między innymi 50 egzemplarzy książki Stara prawda, zawierającej pouczające opowiadania dla włościan, 40 modlitewników z 1867 roku, dziesięć modlitewników z 1872 roku, 19 egzemplarzy $\mathrm{Na}$ uki o ogrodnictwie, dziesięć egzemplarzy żywotów świętych Mikołaja i Jerzego i dziesięć egzemplarzy ośmiu podręczników do religii ${ }^{21}$.

Niestety w odniesieniu do drugiej połowy lat sześćdziesiątych i początku lat siedemdziesiątych XIX wieku praktycznie nie zachowały się żadne informacje (poza częścią raportów księgarni Instytutu Stauropigialnego) o wynikach sprzedaży książek Hałycko-Ruskiej Matycy. Być może jedynym wyjątkiem jest raport księgarni braci Jeleniów z 12 sierpnia 1866 roku na temat dystrybucji publikacji stowarzyszenia, które firma otrzymała 3 i 23 września 1865 roku i których wartość wynosiła 100 złotych reńskich i 50 krajcarów. Wśród nich znajdowało się osiem podręczników szkolnych do religii (po dziesięć egzemplarzy) i modlitewnik z 1864 roku. Publikacje te udało się sprzedać za kwotę 23 złotych reńskich i 15 krajcarów $^{22}$. Tak ubogi materiał źródłowy nie pozwala na dyskusję o tym, które tytuły były najbardziej poszukiwane i jak szybko one się sprzedawały, zwłaszcza na prowincji, we wsiach i w małych miasteczkach.

\footnotetext{
${ }^{20}$ Księga rachunkowa kupujących..., 1. 102-122.

21 Księga rachunkowa kupujących..., 1. 114-115.

22 List braci Jeleniów..., 1866.
} 
Jak wspomniano powyżej, księgarnia Instytutu Stauropigialnego od lipca 1862 roku sprzedawała książki Matycy z 20\% rabatem. Stowarzyszenie dawało tej placówce tak wysokie wynagrodzenie (dla porównania: bracia Jeleniowie otrzymywali prowizje w wysokości $15 \%$, zaś A. Gergowicz - $12 \%$ ) najwyraźniej z kilku powodów: 1. była to największa i najbardziej znana spośród księgarń, które oferowały najszerszą ofertę książek w języku ruskim (ukraińskim); 2. nie ponoszono w tym przypadku kosztów transportu książek, ponieważ wszystkie wydawnictwa Matycy były drukowane przez Instytut Stauropigialny; 3. rozliczenia za wspomniane prace poligraficzne mogły być realizowane częściowo w formie potrącenia z zysków ze sprzedaży książek (zadłużenie stowarzyszenia z tytułu druku jego publikacji automatycznie zmniejszało się po pewnym czasie o kwotę wpływów, oczywiście bez rabatu, ze sprzedanych książek).

W księgarni Instytutu Stauropigialnego w okresie od 1862 roku do lipca 1865 roku sprzedano książki Matycy o wartości 1010 złotych reńskich i 24 krajcarów (z czego towarzystwu przypadło 808 złotych reńskich i 19 krajcarów), a między lipcem 1868 roku a 1870 rokiem rozprowadzono tytuły o wartości 594 złotych reńskich i 90 krajcarów (Matycy z tego otrzymała 475 złote reńskich i 92,5 krajcara). W latach 1862-1865 ruska organizacja otrzymywała od Instytutu średnio 328 złotych reńskich rocznie za sprzedane książki. Stanowiło to średnio około $45 \%$ jej łącznych przychodów ze sprzedaży swoich publikacji. W latach 1867-1870 Matyca przyjmowała od Instytutu Stauropigialnego średnio 187 złotych reńskich rocznie, to jest 32,7\% całkowitego zysku ze sprzedawanych książek. Widać zatem wyraźnie, że udział sprzedaży poprzez księgarnię Instytutu w przychodach Matycy z dystrybucji jej publikacji z czasem malał, choć przez całą dekadę wynosił on około 40\% (Sedliar, 2010, s. 39-40). Na początku lat siedemdziesiątych XIX wieku z powodu dużych dostaw literatury dla innych księgarni i prywatnych dystrybutorów znaczenie Instytutu Stauropigialnego jako głównego sprzedawcy książek Matycy znacznie spadło.

Należy również dodać, że spośród publikacji dostępnych w tej księgarni sprzedano w latach 1862-1863 rocznie około 35-36\% książek według ustalonej ceny ${ }^{23}$, a pod koniec lat sześćdziesiątych XX wieku wskaźnik ten spadł do około 24-26\%, na skutek czego liczba niesprzedanych tytułów stowarzyszenia powoli, ale systematycznie wzrastała ${ }^{24}$. Jeśli chodzi o dystrybucję poszczególnych publikacji, należy zauważyć, że na książki z lat pięćdziesiątych XIX wieku prawie nie było już popytu. „Sbornik Naukowy” nigdy nie był w stanie znaleźć nabywcy,

23 Wykazy książek przekazanych do księgarni..., 1862, 1. 9, 11, 13; Informacje o sprzedaży książek..., 1863, 1. 3.

${ }^{24}$ Informacje o sprzedaży książek..., 1868, 1. 16; Wykazy sprzedanych i niesprzedanych..., 1870, 1. 1-2; Wykaz sprzedanych książek..., 1869, 1. 14; Wykaz książek Hałycko-Ruskiej Matycy..., $1871,1.3 \mathrm{v}, 4 \mathrm{v}$. 
a jedynie podręczniki do religii dla gimnazjów spotykały się z mniejszym bądź większym zainteresowaniem, ale być może nie w takim zakresie, jak by sobie tego życzyło kierownictwo Matycy. Najlepiej rozchodziły się tanie popularne książeczki i modlitewniki (Sedliar, 2010, s. 49-50).

Aby zachęcić potencjalnych czytelników, Hałycko-Ruska Matyca obniżyła ceny niektórych swoich wydawnictw. Zachowane dokumenty odnotowują kilka takich decyzji: walne zgromadzenie z 9 (21) lipca 1864 roku obniżyło ceny kilku książek wydanych w poprzedniej dekadzie („Otchety obshchestva literaturnoho Halitsko-russkoi Matitsy", 1865, s. X), a walne zgromadzenie z 8 (20) lipca 1865 roku podjęło decyzję o zmniejszeniu ceny Biblijnej św. historii starego testamentu... Łuki Cybyka z 1 złotego reńskiego i 30 krajcarów do 90 krajcarów („Otchety zasidanii literaturnoho obshchestva Halitsko-russkoi Matitsy...”, 1865, s. 301), a zarząd towarzystwa w dniu 18 (30) grudnia 1868 roku zniwelował ceny wszystkich podręczników do religii ${ }^{25}$. Obniżki z lata $1864-1868$ były dość znaczne: jeśli po wyjściu z drukarni taki podręcznik kosztował średnio 1 złotego reńskiego i 7 krajcarów, to po wszystkich obniżkach jego cena spadła do 64 krajcarów, co stanowiło $60 \%$ początkowej kwoty. Podejmowano też inne podobne decyzje o zmniejszeniu cen; władze Matycy przekonywały, że chodzi im nie tyle o zysk, ile o dystrybucję książek i dotarcie z nimi do czytelnika.

Ogólnie rzecz biorąc, lata 1862, 1864-1866 i 1870 były udane dla Matycy na polu sprzedaży jej publikacji; odwrotna sytuacja miała miejsce w 1867 roku. W latach tych stowarzyszenie otrzymało ze sprzedaży książek rocznie średnio 6574 złotych reńskich i 581/2 krajcara, to jest 597 złotych reńskich i 68 krajcarów. Stanowiło to $15,95 \%$ wszystkich rocznych zysków stowarzyszenia i $46,74 \%$ kwoty zysków bez uwzględnienia obrotu papierami wartościowymi, spłacanych długów i środków obcych przeznaczonych na nagrody literackie (zob. tabelę 3).

Reakcja Rusinów galicyjskich na rozpowszechnianie publikacji Hałycko-Ruskiej Matycy i ich ocena tych działań zmieniały się nieco w czasie. Właściwie przeobrażeniom ulegały nie tyle same opinie, ile ich ton i częstotliwość ich pojawiania się w przestrzeni publicznej. Ogólnie rzecz biorąc, gdy Rusini galicyjscy publicznie (w prasie) analizowali działalność stowarzyszenia, oceny były dość krytyczne, negatywne, choć wyrażane powściągliwie. Niepochlebne komentarze były spowodowane przede wszystkim niską aktywnością zarządu organizacji i jej ograniczonym programem wydawniczym. Niezadowolenie wywoływał także mniej lub bardziej zrusyfikowany język publikacji Matycy. Jednocześnie ich kolportaż uznawano za mało skuteczny.

25 Protokół posiedzenia zarządu... 1868. 
Tab. 3. Zyski Hałycko-Ruskiej Matycy za lata 1861-187126

\begin{tabular}{|c|c|c|c|c|c|c|c|c|}
\hline \multirow{2}{*}{ Rok } & \multicolumn{2}{|c|}{$\begin{array}{c}\text { Wysokość } \\
\text { dochodu za rok }\end{array}$} & \multicolumn{2}{|c|}{$\begin{array}{c}\text { Wysokość } \\
\text { dochodu II }\end{array}$} & \multicolumn{2}{|c|}{$\begin{array}{c}\text { Zyski ze sprze- } \\
\text { daży książek } \\
\text { towarzystwa }\end{array}$} & \multirow{2}{*}{$\begin{array}{c}\text { Udział } \\
\text { w całko- } \\
\text { witych } \\
\text { zyskach } \\
\text { w \% }\end{array}$} & \multirow{2}{*}{$\begin{array}{c}\text { Udział } \\
\text { w kwo- } \\
\text { cie zys- } \\
\text { ków II } \\
\text { w \% }\end{array}$} \\
\hline & $\begin{array}{l}\text { złote } \\
\text { reńskie }\end{array}$ & $\begin{array}{l}\text { kraj- } \\
\text { cary }\end{array}$ & $\begin{array}{l}\text { złote } \\
\text { reńskie }\end{array}$ & $\begin{array}{l}\text { kraj- } \\
\text { cary }\end{array}$ & $\begin{array}{l}\text { złote } \\
\text { reńskie }\end{array}$ & $\begin{array}{l}\text { kraj- } \\
\text { cary }\end{array}$ & & \\
\hline 1861 & 675 & 28 & - & - & 451 & 28 & 66,83 & - \\
\hline 1862 & 900 & 12 & - & - & 749 & 60 & 83,28 & - \\
\hline 1863 & 2386 & 29 & 1672 & 36 & 435 & 94 & 18,27 & 267 \\
\hline 1864 & 4201 & 35 & 1876 & 35 & 752 & 57 & 17,91 & 40,11 \\
\hline 1865 & 11087 & $71 / 2$ & 2277 & $69^{1 / 2}$ & 972 & 65 & 8,77 & 42,70 \\
\hline 1866 & 4177 & 93 & 1827 & 92 & 666 & 16 & 15,94 & 36,44 \\
\hline 1867 & 4414 & $82^{1 / 2}$ & 1334 & $82^{1 / 2}$ & 146 & 57 & 3,32 & 10,98 \\
\hline 1868 & 3740 & 75 & 1250 & 75 & 514 & 28 & 13,75 & 41,12 \\
\hline 1869 & 1856 & 95 & 1096 & 95 & 463 & 78 & 24,97 & 42,28 \\
\hline 1870 & 3151 & $75^{1 / 2}$ & 1947 & $75^{1 / 2}$ & 1162 & $171 / 2$ & 36,87 & 59,67 \\
\hline 1871 & 4619 & 96 & 779 & 96 & 259 & 58 & 5,61 & 33,28 \\
\hline $\begin{array}{l}\text { Łącznie } \\
\text { w latach } \\
1861-1871\end{array}$ & \multicolumn{2}{|c|}{$41212,281 / 2$} & \multicolumn{2}{|c|}{$14064,561 / 2$} & \multicolumn{2}{|c|}{$6574,581 / 2$} & 15,95 & 46,74 \\
\hline
\end{tabular}

Źródło: opracowanie własne na podstawie: Sedliar, 2010, s. 43, z uzupełnieniami.

Rozpowszechnianie książek oświatowych przez dekanaty Kościoła greckokatolickiego w pierwszej połowie lat pięćdziesiątych zostało przyjęte pozytywnie. Decyzja zarządu Hałycko-Ruskiej Matycy wydawała się całkiem naturalna zarówno ze względu na czołową rolę duchowieństwa przy realizacji ówczesnego programu oświatowego (obejmującego przede wszystkim kształcenie w szkołach podstawowych pod kontrolą Kościoła i wychowanie moralne), jak i mając na uwadze fakt, że księża reprezentowali całą ruską inteligencję. Jednak ten wariant dystrybucji publikacji Matycy po kilku latach przestał być skuteczny.

261 złoty reński $=100$ krajcarów.

27 Łączna suma zysków Matycy bez kupowanych i sprzedawanych papierów wartościowych, spłacanych długów, środków na nagrody literackie. Te fundusze, które zostały odnotowane w zyskach, w rzeczywistości nimi nie były. Na przykład, gdy organizacja kupowała papiery wartościowe, kwota, za którą zostały zakupione, zostawała ujęta w wydatkach, a wartość samych papierów wartościowych zaliczano do zyskaów, co w sumie bilansowej powinno faktycznie dać 0 . 
W drugiej połowie lat sześćdziesiątych XIX wieku proponowano: 1. intensyfikację sprzedaży książek w księgarniach; 2. organizację filii Matycy na prowincji i zlecanie im dystrybucji literatury („Novynky. Iz Pokut'ia”, 1869); 3. aktywne poszukiwania osób prywatnych (zwłaszcza księży), które pomogłyby w rozprowadzaniu publikacji wśród chłopów, w szczególności na jarmarkach i odpustach. Temat zakładania czytelni na wsi nie był jeszcze poruszany — nabrał on znaczenia dopiero w połowie lat siedemdziesiątych.

W galicyjskiej prasie ruskiej z drugiej połowy poprzedniej dekady prawie nie wspominano o dystrybucji publikacji Hałycko-Ruskiej Matycy, a jeśli już to robiono, to jedynie po to, aby skonstatować, że ich sprzedaż idzie powoli (Kachala, 1865, s. 2). Krytyka pod adresem stowarzyszenia nasiliła się na przełomie lat sześćdziesiątych i siedemdziesiątych XIX wieku, kiedy to, w obliczu zmian konstytucyjnych z 1867 roku, szczególnie istotna stała się kwestia oświaty ludu. Kierownictwu towarzystwa zarzucano przede wszystkim sprzedawanie publikacji Matycy głównie we Lwowie, z pominięciem prowincji, w efekcie czego w większości ruskich wsi nawet nie wiedziano o istnieniu tej organizacji. Problem ten został omówiony na jej walnym zgromadzeniu w dniu 27 sierpnia (8 września) 1870 roku. Dyskusja zaowocowała wzrostem liczby sprzedawców publikacji Matycy, a następnie większym zainteresowaniem Rusinów galicyjskich upowszechnianiem jej nowych publikacji.

Od grudnia 1870 roku do listopada 1871 roku zarząd Hałycko-Ruskiej Matycy na swoich zebraniach trzykrotnie podejmował kwestię kolportażu publikacji stowarzyszenia ${ }^{28}$. Pomimo oczywistego wzrostu liczby przekazywanych na sprzedaż książek krytyczny ton wobec działalności kierownictwa towarzystwa nadal był obecny w debacie publicznej. Na początku 1872 roku jeden z korespondentów „Słowa” zapytał Matycę, dlaczego w wielu miastach wschodniej Galicji nie ma punktów sprzedaży jej książek. Pisał on: „Dlatego z tych książek mamy niewiele korzyści, bo trudno znaleźć kogoś, kto pojechałby do Lwowa, a nie każdy z nich chce i ma czas zajmować się książkami, a wysyłka pocztą jest droga. To właśnie wszyscy tracimy” („Novynky. Iz mistechka”, 1872). W „Słowie” bardzo szybko pojawiła się odpowiedź na te zarzuty w postaci artykułu, którego autor - zapewne wywodzący się z zarządu towarzystwa - wyjaśnił sprawę dystrybucji książek Hałycko-Ruskiej Matycy. Był to jedyny przypadek poruszenia tej kwestii w tak obszernym stopniu na łamach ówczesnej prasy (V.D., „Iz L’vova”, 1872).

Tak więc autor tego tekstu przede wszystkim podkreślił, że zarząd towarzystwa od dawna robi wszystko, co możliwe, aby z powodzeniem rozprowadzać swoje publikacje wśród ruskiego społeczeństwa. Sprzedawcy otrzymują korzystną

28 Protokoły posiedzenia zarządu..., 25 listopada (7 grudnia) 1870, 3 (15) marca 1871, 22 października (3 listopada) 1871. 
prowizję w wysokości $20 \%$, książki trafiają do wielu dziekanów i księgarń w dużych miastach. Jako przykłady podano siedem księgarń (oraz biuro Matycy, gdzie również można było kupić książki) i dziewięciu prywatnych dystrybutorów, z których siedmiu było dziekanami lub prodziekanami. W dalszej części artykułu znalazła się ważna uwaga: potencjalni nabywcy wydawnictw Matycy muszą zwracać się do samych księgarzy, aby ci wiedzieli, że istnieje zapotrzebowanie na książki i zamawiali je u ich wydawcy. Autor artykułu podsumował: „Byłoby naprawdę wspaniale, gdyby ruska wykształcona publiczność aktywnie i wszędzie domagała się ruskich książek, ale niestety dzisiaj tak jeszcze nie jest" — ci sami ludzie i kupują książki, i czytają, i piszą, a reszta nic nie robi (V.D., 1872).

Rok 1872, jak już wiemy, był najbardziej udany dla Matycy pod względem liczby przekazanych do dystrybucji publikacji. Nie wiadomo jednak, ile z nich zostało sprzedanych, gdyż nie sporządzono rocznego sprawozdania z działalności towarzystwa. Od 1873 roku aktywność jego zarządu zaczęła spadać, co przez pewien czas wywoływało kolejne krytyczne reakcje w ruskiej prasie. Ksiądz Iwan Naumowicz, znany wówczas autor i wydawca czasopism oraz książek dla ruskich chłopów i mieszczan, kilkakrotnie wypowiadał się na temat upowszechniania literatury oświatowej. Zasugerował on, aby Matyca założyła swoje filie lub agencje na prowincji i wreszcie zorganizowała ,kolportaż dostosowany do potrzeb naszych czytelników" (Naumovych, 1873, s. 2). Ponieważ tak się nie stało, duchowny ten porzucił współpracę z tą organizacją i podjął się zorganizowania innego ruskiego towarzystwa oświatowego - Towarzystwa im. Mychajła Kaczkowskiego. Kilka lat później Naumowicz, wspominając Matycę, która pod koniec lat siedemdziesiątych XIX wieku była praktycznie nieaktywna, powtórzył, że „oni [działacze stowarzyszenia - red.] powinni mieć kolportera, który podróżowałby po całym kraju, od wioski do wioski, z książkami, ikonami, obrazkami i angażowałby członków towarzystwa i prenumeratorów [publikacji - O.S.]" (Naumovych, 1879, s. 233).

Kierownictwo Matycy w połowie lat siedemdziesiątych XIX wieku nie mogło znaleźć nowych form działalności, które przyniosłyby pozytywne i długofalowe skutki. Wcześniejsze decyzje o dystrybucji wydawnictw towarzystwa miały tylko krótkotrwały efekt. Brak źródeł archiwalnych nie pozwala nam ustalić z całą pewnością przyczyn nieskuteczności wysiłków podejmowanych na początku dekady przez organizację w zakresie rozpowszechniania książek. Możemy je co najwyżej wywnioskować na podstawie niektórych faktów. Przede wszystkim mowa tu o decyzji zarządu Matycy z dnia 14 (26) marca 1875 roku o przyjęciu kolejnej oferty pośrednictwa w sprzedaży jej publikacji z odpowiednim rabatem $(20 \%)$, wystosowanej przez Instytut Stauropigialny $(20 \%)^{29}$. Jego przedstawiciele przez półtora miesiąca podkreślali, że akceptują umowę, lecz „, zastrzeżeniem,

29 Protokół posiedzenia zarządu ..., 14 (26) marca 1875. 
że Hałycko-Ruska Matyca nie powinna w ogóle sprzedawać książek przyjętych do magazynu, a jedynie zabierać niezbędną liczbę egzemplarzy do dystrybucji wśród członków"30. Oczywiście Instytut nie chciał, aby jego księgarnia konkurowała z innymi sprzedawcami publikacji stowarzyszenia i pragnął zapewnić sobie pozycję monopolity na tym polu. Zgoda Matycy na ten warunek świadczy o niskiej efektywności dystrybuowania jej wydawnictw przez różnych sprzedawców, a także o stopniowej rezygnacji z dążeń do utrzymania dotychczasowej pozycji organizacji w relacjach z innymi ruskimi towarzystwami oświatowymi - ukrainofilską Proświtą i rusofilskim Towarzystwem im. Mychajła Kaczkowskiego. W rezultacie nawet te publikacje Matycy, które zbierały dobre recenzje w prasie (na przykład Zołota knyżoczka I. Naumowicza) i miały duże szanse na rynkową popularność, były bardzo trudno dostępne na prowincji („Pys'mo iz Kolomyishchyny”, 1875, s. 274, 276). Brak właściwego ewidencjonowania dystrybucji książek i wpływów finansowych uzyskiwanych $\mathrm{z}$ tego tytułu oraz nieorganizowanie walnych zgromadzeń i nieprzygotowywanie rocznych sprawozdań tylko pogłębiają smutny obraz działalności zarządu Hałycko-Ruskiej Matycy po 1872 roku.

Aby ocenić skuteczność dystrybucji publikacji Hałycko-Ruskiej Matycy do połowy lat siedemdziesiątych XIX wieku, musimy wziąć pod uwagę kilka ważnych czynników. Po pierwsze, chociaż miała ona za zadanie zajmować się szerzeniem oświaty wśród ludu, w rzeczywistości jej przywódcy uważali ją przede wszystkim za towarzystwo literackie. W związku z tym zawsze byli bardziej zainteresowani wydawaniem literatury niż jej dystrybucją. Na skutek tego Matyca zajmowała się raczej wyszukiwaniem autorów tekstów, zbieraniem i ocenianiem rękopisów czy tematyką wydawanych publikacji niż ich sprzedażą, a tym bardziej rozwijaniem oświaty wśród ruskich chłopów i drobnomieszczan. Kolportaż książek był naprawdę ważną kwestią dla przywódców Matycy tylko w niektórych okresach — w latach 1850-1854, 1864-1865 i 1870-1873.

Po drugie, w kontekście upowszechniania się oświaty, zwykli ludzie byli uważani przez przywódców Matycy za biernych odbiorców wiedzy, która byłaby przekazywana lub udostępniana przez inteligencję, przede wszystkim księży greckokatolickich. Dlatego zarząd organizacji nie zastanawiał się, jak zainteresować ruskiego chłopa zakupem i przeczytaniem wydawanych przez nią książek - mieli to zrobić dystrybutorzy, każdy według własnego uznania. Dla liderów Matycy dystrybucja wydawnictw ograniczała się do wysyłania ich do księgarni lub prywatnych sprzedawców, zbierania pieniędzy za sprzedane egzemplarze, prowadzenia korespondencji i ewidencji sprzedaży. W protokołach posiedzeń zarządu i walnych zgromadzeń towarzystwa nie ma żadnej wzmianki o dyskusjach na temat postrzegania przez chłopów i drobnomieszczan publikacji

30 Wyciąg z umowy..., 1875, 1. 28. 
Matycy, ich uwagach i życzeniach w tej mierze. Generalnie kwestia odbioru literatury ruskiej przez czytelników spoza inteligencji zaczęła być publicznie omawiana dopiero w latach siedemdziesiątych XIX wieku (od 1873 roku), kiedy to pojawiły się we wsiach ruskich czytelnie, a aktywność Matycy gwałtownie spadła.

Po trzecie, należy mieć na uwadze niesprzyjające warunki dla efektywnej dystrybucji publikacji towarzystwa. Brak ruskich księgarń poza Lwowem, niski poziom piśmienności wśród ruskich chłopów i drobnomieszczan, ich ubóstwo, znikoma aktywność społeczna większości inteligentów, wreszcie brak ogólnie obowiązujących i akceptowanych przez całe społeczeństwo norm ukraińskiego języka literackiego bardzo utrudniały dystrybucję książek Matycy. W tych okolicznościach wszelkie osiągnięcia w wydawaniu i rozpowszechnianiu ruskich publikacji, zwłaszcza w latach pięćdziesiątych XIX wieku, Rusini uznawali za sukces. Stanowisko kierownictwa Hałycko-Ruskiej Matycy przez lata było niezmienne: robimy wszystko, co możliwe, aby wypełniać nasze zadania. Inteligencja ruska przychylnie odnosiła się do tego przekonania, a jego krytyka — jeśli się pojawiała - była dość powściągliwa.

Tym samym formuła dystrybucji wydawnictw Hałycko-Ruskiej Matycy, z dominującą rolą księgarni Instytutu Stauropigialnego we Lwowie oraz prywatnych dystrybutorów na prowincji, była uznawana za optymalną i nie budziła większych zastrzeżeń. Intensywność sprzedaży książek towarzystwa, a zwłaszcza stopień ich docierania do masowego czytelnika, nie spełniała jednak oczekiwań aktywnej części ruskiej inteligencji. Chociaż podnoszone publicznie zastrzeżenia przeciwko Matycy dotyczyły głównie jej programu wydawniczego, dystrybucja jej publikacji także budziła niepochlebne spostrzeżenia, zwłaszcza od 1870 roku. Okoliczności szybko się zmieniały, zapotrzebowanie na literaturę oświatową stale rosło, a strategia zarządu organizacji w zakresie jej wydawania i dystrybucji w końcu lat sześćdziesiątych XIX wieku pozostała prawie taka sama jak dwie dekady wcześniej. Na początku kolejnej dekady stowarzyszenie próbowało ożywić swoje działania na tym polu, ale efekt był krótkotrwały.

Na ogół miłośnicy książek mogli, choć z pewnym trudem, nabyć wszystkie publikacje Matycy. We Lwowie było to łatwe, jednak na prowincji sprawy miały się gorzej. Wśród księgarń dominowała ta należąca do Instytutu Stauropigialnego, którą pod pewnymi względami można nawet nazwać oficjalnym dystrybutorem wydawnictw stowarzyszenia. Na prowincji główną rolę w rozprowadzaniu publikacji Hałycko-Ruskiej Matycy odgrywali indywidualni sprzedawcyksięża. Dystrybutorzy prywatni mieli przede wszystkim: 1. zrekompensować brak ruskich księgarń poza głównymi ośrodkami oraz 2. skrócić drogę książki do ruskiego chłopa. Ich znaczenie w procesie sprzedaży wydawnictw towarzystwa było duże, ale nieprofesjonalni dystrybutorzy pracowali dorywczo i nie byli równomiernie rozmieszczeni we wszystkich powiatach Galicji Wschodniej. Rola 
księgarń była mniejsza, ale ważna, ponieważ stanowiły one dodatkową opcję dystrybucji ruskich książek w miastach. Niestety zarządowi Matycy nie udało się przygotować stałego schematu dystrybucji swoich publikacji w całej Galicji Wschodniej. Towarzystwo dzięki swoim wydawnictwom było wprawdzie obecne wśród miejscowych Rusinów, ale w niewystarczającym stopniu i nie wszędzie. Nowe ruskie organizacje oświatowe (Proświta i Towarzystwo im. Mychaiła Kaczkowskiego) próbowały naprawić ten stan rzeczy, ale proces efektywnego wprowadzania książki edukacyjnej do codzienności ruskich chłopów miał trwać następnych kilkadziesiąt lat, aż do początku XX wieku.

\section{BIBLIOGRAFIA}

\section{ARCHIWALIA}

Adres zarządu Hałycko-Ruskiej Matycy do dekanatów Kościoła greckokatolickiego, 18 (30) marca 1868, Centralne Państwowe Archiwum Historyczne Ukrainy we Lwowie (dalej - CPAHUL), zesp. 148 (Naukowo-literackie towarzystwo Hałycko-Ruska Matyca, m. Lwów), op. 1, sygn. 20, 1. 35-36v.

Informacje o sprzedaży książek Hałycko-Ruskiej Matycy w księgarni Instytutu Stauropigialnego za okres od 1 lipca 1867 do 30 czerwca 1868 roku, CPAHUL, zesp. 148, op. 1, sygn. 71, 1. 16.

Informacje o sprzedaży książek Hałycko-Ruskiej Matycy za okres od lipca 1862 do końca lutego 1863 roku, CPAHUL, zesp. 148, op. 1, sygn. 56, 1. 3.

Księga rachunkowa kupujących i sprzedanych egzemplarzy Stowa o pułku Igora, Czytanki M. Szaszkiewicza i innych książek z lat 1848-1872, CPAHUL, zesp. 129 (Lwowski Instytut Stauropigialny), op. 2, sygn. 1217.

List braci Jeleniów do zarządu Hałycko-Ruskiej Matycy z 12 sierpnia 1866 roku,,CPAHUL, zesp. 148, op. 1, sygn. 119, 1. 29-30.

List Instytutu Stauropigialnego do zarządu Hałycko-Ruskiej Matycy z 14 lipca 1853 roku, CPAHUL, zesp. 148, op. 1, sygn. 39, 1. 13.

List księdza Stefana Krynickiego do nieznanej osoby (księdza M. Kuzemskiego?) z 4 października 1850 roku, CPAHUL, zesp. 148, op. 1, sygn. 36, 1. 5.

List zarządu Hałycko-Ruskiej Matycy do B.D. Neranziego z 2 kwietnia 1855 roku, CPAHUL, zesp. 148, op. 1, sygn. 35, 1. 24.

List zarządu Hałycko-Ruskiej Matycy do księdza Kornelia Lewickiego z 15 (27) maja 1852 roku, CPAHUL, zesp. 148, op. 1, sygn. 13, 1. 27-27v.

Protokół z posiedzenia zarządu Hałycko-Ruskiej Matycy z 18 (30) grudnia 1868 roku, CPAHUL, zesp. 148, op. 2, sygn. 7, 1. 20-20v.

Protokół z posiedzenia zarządu Hałycko-Ruskiej Matycy z 2 (14) listopada 1856 roku, CPAHUL, zesp. 148, op. 1, sygn. $28,1.8-8 \mathrm{v}$.

Protokół z posiedzenia zarządu Hałycko-Ruskiej Matycy z 27 marca 1850 roku, CPAHUL, zesp. 148, op. 1, sygn. 15, 1. 2-4.

Protokół z posiedzenia zarządu Hałycko-Ruskiej Matycy z 14 (26) marca 1875 roku, CPAHUL, zesp. 148, op. 2, sygn. 7, 1. 36v. 
Protokoły z posiedzeń zarządu Hałycko-Ruskiej Matycy z 25 listopada (7 grudnia) 1870, 3 (15) marca 1871 oraz 22 października (3 listopada) 1871 roku, CPAHUL, zesp. 148, op. 2, sygn. 7, 1. 30-32

Sprawozdanie Instytutu Stauropigialnego na temat sprzedaży książek Hałycko-Ruskiej Matycy za okres od 1 czerwca 1853 roku do 31 października 1854 roku, 31 października 1854 roku, CPAHUL, zesp. 148, op. 1, sygn. 34, 1. 44.

Sprawozdanie Instytutu Stauropigialnego na temat sprzedaży książek Hałycko-Ruskiej Matycy za okres od 1 listopada 1854 roku do końca października 1855 roku, CPAHUL, zesp. 148, op. 1, sygn. $34,1.51-52$.

Sprawozdanie Instytutu Stauropigialnego o sprzedaży książek Hałycko-Ruskiej Matycy za okres od 1 czerwca 1852 roku do 31 maja 1853 roku, 31 maja 1853 roku, CPAHUL, zesp. 148, op. 1, sygn. $39,1.3 \mathrm{v}-4$.

Sprawozdanie J. Rosenheima do zarządu Hałycko-Ruskiej Matycy, 16 stycznia 1854, CPAHUL, zesp. 148 , op. 1, sygn. $34,1.38$.

Wyciąg z umowy pomiędzy Hałycko-Ruską Matycą a Instytutem Stauropigialnym z 23 kwietnia (5 maja) 1875 roku, CPAHUL, zesp. 148, op. 1, sygn. 81, 1. 28.

Wykaz książek Hałycko-Ruskiej Matycy znajdujących się w księgarni Instytutu Stauropigialnego według stanu na 31 grudnia 1870 roku, CPAHUL, zesp. 148, op. 1, sygn. 78, 1. 3v, 4v.

Wykaz książek Hałycko-Ruskiej Matycy sprzedanych w księgarni Instytutu Stauropigialnego w okresie od 1 lipca 1868 roku do 30 czerwca 1869 roku, CPAHUL, zesp. 148, op. 1, sygn. 75, 1. 14.

Wykazy książek przekazanych w celu sprzedaży do księgarni Instytutu Stauropigialnego, CPAHUL, zesp. 148, op. 1, sygn. 49, 1. 9-13.

Wykazy sprzedanych i niesprzedanych książek Hałycko-Ruskiej Matycy w księgarni Instytutu Stauropigialnego za okres od 1 lipca 1869 roku do 30 czerwca 1870 roku, CPAHUL, zesp. 148, op. 1, sygn. 73, 1. 1-2.

\section{OPRACOWANIA}

Dopytailo, I. (1851). Z Tarnopil'skoho okruha. Zoria Halytska, 8 marca, s. 158-159.

Kachala, St. (1865). Yaka yest' tsil' Halytsko-ruskoi Matytsi? Slovo, 29 marca, s. 1-3.

Kimball, Stanley B. (1973). The Austro-Slav Revival: A Study of Nineteenth-Century Literary Foundations. Transactions of the American Philosophical Society, 63(4), 1-83.

L'viv, dnia 26. Liutoho 1864 (1864). Vistnyk chasopys' uriadova dlia Rusynov Avstriiskoi derzhavy, 5 marca, s. 55-56.

Naumovych, I. (1873). Iz Skalata. Slovo, 9 września, s. 2-3.

Naumovych, I. (1879). Kto vinovat? Nauka, 1 sierpnia, s. 228-234.

Novynky (1869). Slovo, 10 lipca, s. 4.

Novynky. Iz mistechka (1872). Slovo, 17 stycznia, s. 4.

Novynky. Iz Pokut'ia (1869). Slovo, 10 lutego, s. 4.

Otchet zasidaniia obshchogo sobraniia chlenov Halitsko-russkoi Matitsy otbyvshohosia na d. 27. Avhusta (8. Sent.) 1870. ([1871]). Literaturnyi Sbornik, izdavaiemyi Halitsko-russkoiu Matitseiu. 1870 , s. 117-133.

Otchety zasidanii literaturnoho obshchestva Halitsko-russkoi Matitsy na dniakh 6, 7 i 8 (18, 19 i 20) Yul'ia 1865 hoda (1865). Naukovyi Sbornik, izdavaiemyi literaturnym obshchestvom Halitsko-russkoi Matitsy. 1865, I-IV, s. 283-307.

Pys'mo iz Kolomyishchyny (1875). Nauka, czerwiec, s. 272-276. 
Sedliar, O. (2010). Rozpovsiudzhennia vydan' tovarystva „Halyts'ko-rus'ka matytsia” (1848-1870 rr.). Visnyk L'vivs'koho universytetu. Seriia knyhoznavstvo, bibliotekoznavstvo ta informatsiini tekhnolohii, 5, 28-51.

Spravosdan'ie s zasidanii „Halitsko-Russkoi Matitsy” v dniakh 7., 8. i 9. russk. Yuliia 1864., sostavlennoie na osnovi stenohrafichnykh zapisok i protokoliarnykh aktov (1865) // Naukovyi Sbornik, izdavaiemyi literaturnym obshchestvom Halitsko-russkoi Matitsy, I-IV, XXXI-LXXVII.

Sukhyi, O. (2003). Vid rusofil'stva do moskvofil'stva (rosiis'kyy chynnyk u hromads'kii dumtsi ta suspil'no-politychnomu zhytti halyts'kykh ukrayintsiv u XIX stolitti). L'viv: LNU imeni Ivana Franka.

[Ukhvaly Soboru rus'kykh vchenykh 1 (13) bereznia 1850 r.] (1850). Zoria Halytska, 10 kwietnia, $169-170$.

V.D. (1872). Iz L'vova. Slovo, 24 stycznia, 3.

Wendland, A.V. (2015). Rusofily Halychyny. Ukrayins'ki konservatory mizh Avstriieiu ta Rosiieiu, 1848-1915. L’viv: Litopys.

OLEKSANDR SEDLIAR

\section{THE DISTRIBUTION OF PUBLICATIONS OF THE SOCIETY HALYTSKO- RUSKA MATYTSIA IN THE MIDDLE OF THE 19TH CENTURY: ORGANIZATION, QUANTATIVE MEASUREMENT, PUBLIC ASSESSMENTS}

\section{Summary}

The main task of the Ruthenian (Ukrainian) society Halytsko-Ruska Matytsia (Galician-Ruthenian Matytsia), founded in Lviv in 1848, was to publish and distribute cheap literature for the people. During the 1850s, 1860s and 1870s there were three groups of distributors: (1) the bookstore of the Stauropegion Institute in Lviv; (2) other bookstores that belonged to non-Ruthenians; (3) private distributors, almost exclusively Greek Catholic priests in the province. Most of Matytsia's publications were sold by the bookstore of the Stauropegion Institute (approximately $40 \%$ in value in the 1850s and mid-1860s). It is known that in the 1850s 5 other bookstores collaborated with Matytsia, in the 1860 s and early 1870 s -15 other bookstores in 11 cities. The number of private distributors was significant - almost 120 in the 1850 s and almost 70 at the turn of the 1860 s and 1870s. The bookstores received a commission for the sale of books (from 10 to $20 \%$ of their value), and individual distributors often worked for free. Halytsko-Ruska Matytsia most actively sent its books for sale in 1850-1854, 1864-1865 and 1870-1873. Matytsia's publications were intended for different readers, intelligentsia and peasants. The bookstore of the Stauropegion Institute offered a full range of publications, while other bookstores focused primarily on quick sales and ordered books which were most popular among peasants - educational and religious-educational. Despite the efforts of the Matytsia managers to distribute publications, they were not available to most Ruthenian peasants, which sometimes provoked criticism in the press.

KEY WORDS: history of Ukrainian books, history of bookselling, bookstores in Galicia, education of the people in the XIX century, Greek Catholic clergy, Halytsko-Ruska Matytsia Society 